\title{
Vegetation and Pollen Rain Relationship from the Tropical Atlantic Rain Forest in Southern Brazil
}

\author{
Hermann Behling ${ }^{1 *}$ and Raquel R. B. Negrelle ${ }^{2}$ \\ ${ }^{1}$ Department of Palynology and Climate Dynamics; Albrecht-von-Haller-Institute for Plant Sciences; University \\ of Göttingen; hermann.behling@bio.uni-goettingen.de; Untere Karspüle 2; 37073 Göttingen - Germany. ${ }^{2}$ Lab. \\ OIKOS; Departmento de Botânica;Universidade Federal do Paraná; negrelle@ufpr.br; C. P. 19023; 81531-970; \\ Curitiba - PR - Brasil
}

\begin{abstract}
The relationship between the southern Brazilian tropical Atlantic lowland rain forest and modern pollen rain was studied by pollen traps. The study was carried out on a one hectare plot undisturbed rain forest of the reserve Volta Velha and two secondary forests, \pm 50 and 7 years old. About 248 identified tree, shrub and herb species (excluding epiphytes) of 50 families were represented by 126 different pollen and spore types (including non-local taxa). The calculated average influx of pollen rain from the native Atlantic rain forest was 12465 pollen grains per $\mathrm{cm}^{2}$ and year. The influx from the \pm 50 years old and from the 7 years old secondary forest was relatively low (4112 and 3667 grains per $\mathrm{cm}^{2}$ and year, respectively) compared to the undisturbed rain forest. The occurrence of pollen grains of herbs and fern spores were significantly higher in the secondary forests than in the undisturbed rain forest.
\end{abstract}

Key words: Southern Brazil, modern pollen rain, tropical Atlantic rain forest, secondary forest

\section{INTRODUCTION}

The relationship between tropical rain forest and modern pollen rain has been poorly studied, despite the importance for the interpretation of fossil pollen records from southern Brazil including the study site. To study the relationship between modern pollen rain and vegetation from which the pollen were originated, we installed pollen traps in a one hectare plot of undisturbed native rain forest and in two different secondary forests in the Atlantic lowland. The study area was located in the biological reserve Volta Velha (26004' S, 48038' W, 9 m a.s.1.) which was part of the biosphere reserve Mata Atlântica and located in the Itapoá district, the northernmost area of Santa Catarina State. The site was $5 \mathrm{~km}$ distant from the Atlantic Ocean and $25 \mathrm{~km}$ distant from the Serra do Mar mountain range (Fig. 1). The study area lied in a flat or slightly undulated coastal plain, formed by Quaternary sediments of fluvial and marine origins (Martin et al., 1988). Palaeodunes, small active rivers and inactive river channels, filled with sediments, were found in the reserve.

According to Nimer (1986) and the Atlas de Santa Catarina (1986) the climate of the study region was characterized as meso-thermic with no frosts and very humid without a dry season. The nearest weather station, São Francisco do Sul, was about $15 \mathrm{~km}$ south of the study area. The station recorded a mean annual rainfall of $1875 \mathrm{~mm}$ and a mean annual temperature of $21.4{ }^{\circ} \mathrm{C}$. The corresponding data for Joinville (about $30 \mathrm{~km}$

\footnotetext{
* Author for correspondence
} 
southwest of the study area) were $2171 \mathrm{~mm}$ and $20.3^{\circ} \mathrm{C}$, respectively.

The undisturbed $25 \mathrm{~m}$ tall stratified Atlantic rain forest of the one hectare plot comprises 248 identified tree, shrub and herb species (excluding epiphytes) in 50 families (Angiospermae, Gymnospermae and Pteridophyta). The most important tree families were Lauraceae, Euphorbiaceae, Anacardiaceae, Myrtaceae and Sapotaceae. Dominant tree species were Tapirira guianensis (Anacardiaceae), Aparisthmium cordatum (Euphorbiaceae) and Ocotea acipahylla (Lauraceae). Important understory trees and shrubs were Geonoma sp., Melastomataceae such as Miconia chartaceae, Miconia hymenonervia, Ossaea sanguinea and Rubiaceae like Psychotria sp.. The rain forest was also rich in lianas and epiphytes. Contrary to other tropical forests in $\mathrm{S}$ Brazil (Klein, 1978), there was also a dense soil covered with Bromeliaceae (mainly Nidularium innocentii). More detailed data on the floristic inventory is given in Negrelle (1995). The two secondary forests referred here, were situated close to the area of the undisturbed forest. The two areas of secondary forest differed in their age, one was around 50 years old and the other was 7 years old. The \pm 50 years old secondary forest was dense and around $20 \mathrm{~m}$ tall and its floristic composition was similar to the native rain forest. The 7 years old secondary forest was less dense, around $5 \mathrm{~m}$ tall, had an open canopy and a different and less diverse plant composition, dominated by Myrtaceae (Campomanesia guavirova), Asteraceae (Vernonia sp.) and Pteridophyta. Huge areas of native forests in the coastal plain, next to the study area, were replaced by Pinus forests in the last decades (Negrelle, 1995). Furthermore, small areas of pasture occured close to the study area.
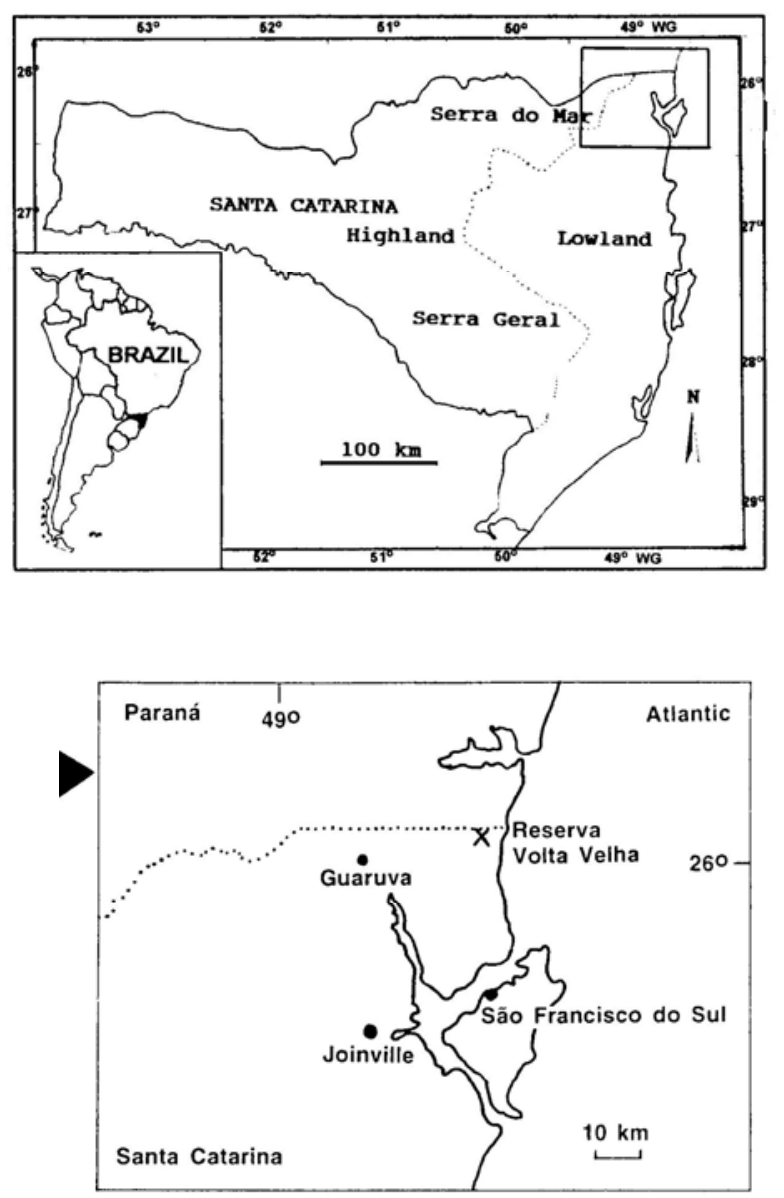

Figure 1 - Location of the study area at Santa Catarina State, Southern Brazil. 


\section{METHODS}

The preparation of the plastic funnel pollen traps was performed as described by Bush (1992). In a plot area of $50 \times 200 \mathrm{~m}$ native rain forest, divided in $10 \times 20 \mathrm{~m}$ sections (plot area is shown in the influx 3-D representation in Fig. 3), 15 pollen traps in three parallel lines were installed. A distance of $40 \mathrm{~m}$ was left between each trap. The distance between line I and line II was $20 \mathrm{~m}$ and between line II and line III, $10 \mathrm{~m}$. Further 5 pollen traps each were installed in irregular distances between 15 and $25 \mathrm{~m}$, in the 7 years and \pm 50 years old secondary forest. The ages of the two secondary forests were obtained from former farmers. All uncovered traps were located in the soil. Funnels were installed around $15 \mathrm{~cm}$ above the soil. Each pollen trap had a collecting area of $72.3 \mathrm{~cm}^{2}$. The time period of installation for all pollen traps was from December $22^{\text {nd }}, 1993$ to December $10^{\text {th }}, 1994$. Three pollen traps (one of each different area) were not effective. The Whatman GF/D filter and the viscose rayon of all pollen traps were removed and placed in plastic packs in the field.

In total, 22 pollen trap samples, filter and rayon, were treated with $50 \mathrm{ml}$ of $5 \%$ potassium hydroxide $(\mathrm{KOH})$ solution for one night to free the pollen and spores. Five tablets of Lycopodium clavatum (one tablet containing $13900 \pm 300$ spores) were added to each sample for concentration calculations before treatment. To extract the pollen and spores, the samples were squashed and washed several times with distilled water. Furthermore the extract and the residue (filter and rayon) were treated with $50 \mathrm{ml}$ of 47 $52 \%$ hydrofluoric acid (HF) for a minimum of one night to destroy minerals and the filter pieces. HF destroyed only a part of the rayon. The samples (rest of the rayon) were again squashed and washed several times. After acetolysis the samples were mounted in a glycerin medium. The pollen grains were counted in all samples to a minimum of 500. Pollen and spores were identified by reference to the author's own type collection, containing about 1400 Brazilian taxa (Behling, 1993).

The computer programs TILIA and TILIAGRAPH were used for calculations and the construction of the pollen diagram. The pollen diagram (Fig. 2) shows percentages for the most frequent taxa. The sum for percentage and concentration calculations based on the total pollen sum excluded aquatic taxa and spores. In the pollen diagram, pollen trap number $1-14$ are from the native Atlantic rain forest, $15-18$ are from the \pm 50 years old secondary forest and $19-22$ from the 7 years old secondary forest. Average percentages of the counted taxa of all pollen traps from each site is given in the diagram under $\mathrm{A}$ (native Atlantic rain forest), B ( \pm 50 years old secondary forest) and C (7 years old secondary forest). Pollen rain data for the most frequent taxa are given in Tables 1,2 and 3. Pollen rain compared with number of individuals of the one hectare plot is presented in Table 4. The influx (pollen grains $\mathrm{cm}^{-2} \mathrm{yr}^{-1}$ ) for each pollen trap in the native rain forest plot from 8 different taxa is shown in Fig. 3.

\section{RESULTS AND DISCUSSION}

\section{Modern pollen rain}

In total, 126 different pollen and spore types (15 unknown) were recorded from 22 pollen traps. Exotic pollen taxa were primarily Pinus, originating from surrounding plantations, and Casuarina, Cupressaceae and Zea may, probably from gardens and agriculture fields near the studied area. Aquatics, such as Typha, also came from outside of the study area. There were relatively high values of Araucaria angustifolia transported by wind from the highland (maximum was $0.6 \%$ of the total pollen sum, influx was between $0-111$ grains $\mathrm{cm}^{-2} \mathrm{yr}^{-1}$ ). Andean pollen taxa were also detected, transported over very long distances, including Alnus $(0.1 \%$, influx was 5 grains $\left.\mathrm{cm}^{-2} \mathrm{yr}^{-1}\right)$, Ephedra (1 grain) and Nothofagus (2 grains).

Pinus pollen grains, originated from plantations close to the study sites, was an excellent indicator of the effectiveness of the installed pollen and provided an independent tool for verifying the results. The more or less low influx variation of Pinus pollen (Fig. 3) between the pollen traps showed a good efficiency of the traps. The average pollen influx of Pinus changed very little between groups A, B and C. Influx and the frequency of the different pollen and spore taxa of the pollen assemblages of the traps were relatively variable within the same forest, and between undisturbed and secondary forests (Figs. 2 and 3). 
Pollen rain from the undisturbed Atlantic rain forest

The modern pollen rain had an average influx of 12465 grains $\mathrm{cm}^{-2} \mathrm{yr}^{-1}$ and was marked by the dominance of tropical trees including some shrubs $(88 \%)$. Herbs $(5.5 \%)$, epiphytes $(1 \%)$ and ferns $(7.2 \%)$ had a low representation (Table 1). The pollen diagram (Fig. 2) shows roughly three groups. The first group contained taxa which were abundant in all pollen traps, especially Tapirira guianensis, followed by Alchornea/Aparisthmium, Myrtaceae, Myrsine, Arecaceae and Melastomataceae. The second group comprised frequent taxa, but only in one or two pollen traps, like Cabralea, Sloanea, Pera, Alseis floribunda, Maprounea and Vernonia. The third group was formed by relatively rare taxa, but represented in most of the pollen assemblages, such as Moraceae/Urticaceae, Didymopanax, and Weinmannia. A fourth group included species which were found by single pollen grains in some traps (not presented in the diagram).

\section{Comparisons between the pollen rain from secondary forests and the undisturbed rain forest}

The average influx of 4112 grains $\mathrm{cm}^{-2} \mathrm{yr}^{-1}$ in the \pm 50 years old and 3667 grains cm-2 $\mathrm{yr}^{-1}$ in the 7 years old secondary forest was relatively low in comparison to the undisturbed rain forest. Taxa of trees and shrubs in the \pm 50 years old and in the 7 years old forest $(80 \%$ and $73.9 \%$ respectively) were well represented, but herbs were significantly higher ( $10.3 \%$ and $20 \%$ respectively) than in the undisturbed rain forest (Tables 1, 2 and 3). Fern spores were very abundant $(38.2 \%$ and $390 \%$, respectively). The order of abundance of pollen grains of secondary forests was also different in comparison to the native rain forest. This could be related to the different floristic composition. The pollen rain of the \pm 50 years old secondary forest was more similar to the undisturbed rain forest than the 7 years old secondary forest. Percentages of Poaceae pollen grains were very high in the 7 years old secondary vegetation, and probably originated from grasses growing beneath the open canopy.

\section{Relationship between pollen rain and native Atlantic rain forest}

While comparing pollen rain with vegetation it must be considered: 1 . The area of the pollen traps was small relative to the total pollen rain area of the study site. 2. Small flowers or anthers from flowering plants could drop directly into the pollen traps under the plants and might have a strong local effect. 3. The local pollen rain included also some pollen and spores, which were transported over short distance (neighbouring regions) or long distance to the study area. 4. Interspecific differences in pollen production and dispersal power occured. 5. The number of trees of each species on the one hectare plot was based on a trunk with a DBH (diameter at breast height $=130$ $\mathrm{cm})>5 \mathrm{~cm}$. Not every individual produce pollen in a juvenile stage even with a DBH $>5 \mathrm{~cm}$. Comparison between collected pollen rain of each pollen trap and their surrounding vegetation (radius of $5 \mathrm{~m}$ ) had been carried out, but because of the restrictions (especially point 5) it was too difficult and to complex too exclude juvenile and no-flowering trees.

Due to these restrictions, comparisons between pollen taxa and their number of individuals in the one hectare plot were somewhat limited. Around 248 identified tree, shrub and herb species (excluding epiphytes) in 50 families (Angiospermae, Gymnospermae and Pteridophyta) from the Atlantic rain forest were represented by 126 different pollen and spore types in the pollen traps (including taxa which were not found in the one hectare plot). Comparison between the most frequent pollen taxa and their number of individuals (Table 4) showed that several taxa were not found in the one hectare plot. Pollen taxa like Pinus, Moraceae/Urticaceae, Alseis floribunda, Cyperaceae and Trema come from species surrounding the study area. Pollen grains like Araucaria angustifolia and Alnus were transported by wind over long distance.

The order of frequency of pollen taxa did not correspond to the order of density of all species, but abundant pollen taxa such as Tapirira guianensis and Alchornea/Aparisthmium (group $1)$, were corresponded to high density species. Less frequent pollen taxa like Clethra, Ilex (group 3) were corresponded to low density species in the one hectare plot. Cabralea, represented only by one tree, had a very strong local effect (Fig. 3). Local effects were also found in many other taxa (group 1 and 2), as shown by the high percentage or influx values from in general only one trap sample (Figs. 2 and 3). Several families with abundant tree individuals with a DBH $>5 \mathrm{~cm}$ (not shown in Table 4) such as Lauraceae (239 species), Monimiaceae (81), Olacaceae (61), 
Sapotaceae (59), Fabaceae (41), Chrysobalanaceae (39) and Annonaceae (32) were missing, or rarely represented in the pollen assemblages. Several rare species, which occured in the one hectare plot, were not found by pollen in the traps. Interspecific differences in pollen production and dispersal power could be responsible for some anomalies. For example Ocotea (121), a member of the Lauraceae, had very fragile pollen grains and was usually not found in the pollen traps.

Studies on pollination (Negrelle, 2002), based on flower structure and bibliographic references, showed that trees species of the study area with a DBH $>10 \mathrm{~cm}$ (97 different species) were $94.9 \%$ entomophilous, $3.1 \%$ ornitomophilous, $1 \%$ chiropteromophilous and $1 \%$ anemophilous. This did not exclude the possibility of wind transportation of pollen grains from e. $\mathrm{g}$. entomophilous tree species. From the trees of the one hectare plot only Podocarpus was wind pollinated. Other wind-pollinated trees were found outside the study area; Pinus, Araucaria angustifolia and Alnus. Interestingly one single female Araucaria angustifolia tree, introduced in the study area, was pollinated by wind transported pollen grains from the highland (at least $25 \mathrm{~km}$ away). The average Araucaria pollen rain was about $32 \mathrm{~cm}^{-2} \mathrm{yr}^{-1}$ in this area.

Pollen transport from rain forest species could be very limited and transported only over short distances. This was very clearly shown for instance by Cabralea (Fig. 3), which was found by only one tree in the one hectare plot. Influx divided by individuals (Table 4) could be roughly an indicator of pollen production. High values were found for instance by Tapirira guianensis, Myrsine, Weinmannia and Didymopanax indicating relatively high pollen dispersal power, whereas for instance Myrtaceae, Ilex and Matayba had low values, thus a relatively low pollen dispersal power. These taxa were overrepresented, or under-represented respectively, in the pollen assemblages.

Table 1 - Average pollen rain data in percent (based on total pollen sum) and in influx (pollen grains cm- $\mathrm{yr}^{-1}$ ) of the native Atlantic rain forest (based on 14 pollen traps).

\begin{tabular}{|c|c|c|c|c|}
\hline $\begin{array}{r}\text { Taxa } \\
\end{array}$ & $\%$ & Min-Max & Influx & Min-Max \\
\hline Tapirira guianensis & 24.9 & $2.2-70.2$ & 3610 & $192-15806$ \\
\hline AlchornealAparisthmium & 12.0 & $2.6-28.5$ & 1485 & $408-4524$ \\
\hline Myrsine & 6.8 & $1.6-11.3$ & 752 & $349-1098$ \\
\hline Myrtaceae & 6.1 & $1.8-15.4$ & 720 & $223-2416$ \\
\hline Sloanea & 5.4 & $0.2-39.1$ & 736 & $22-6142$ \\
\hline Cabralea & 4.3 & $0-42.9$ & 412 & $0-3825$ \\
\hline Pera & 4.1 & $0.2-42.4$ & 426 & $22-4235$ \\
\hline Arecaceae (Other) & 3.0 & $0.8-6.3$ & 340 & $148-659$ \\
\hline Melastomataceae & 2.7 & $0.4-14.3$ & 322 & $35-2031$ \\
\hline Pinus & 2.1 & $0.7-4.21$ & 229 & $98-418$ \\
\hline Moraceae/Urticaceae (P2) & 1.8 & $0.6-3.5$ & 205 & $66-320$ \\
\hline Weinmannia & 1.6 & $0.4-5.4$ & 183 & $44-495$ \\
\hline Poaceae & 1.5 & $0.4-2.7$ & 173 & $35-296$ \\
\hline Tubuliflorae (Asteraceae) & 1.5 & $0-3.3$ & 179 & $0-467$ \\
\hline Maprounea & 1.3 & $0-12.9$ & 143 & $0-1399$ \\
\hline Alseis floribunda & 1.2 & $0-16.3$ & 223 & $0-3104$ \\
\hline Vernonia & 1.2 & $0-10.8$ & 134 & $0-1229$ \\
\hline Clethra & 1.2 & $0-6.2$ & 153 & $0-668$ \\
\hline Didymopanax & 1.2 & $0.4-2.6$ & 155 & $42-480$ \\
\hline Ilex & 0.9 & $0-3.5$ & 93 & $0-349$ \\
\hline Syagrus romanzoffiana & 0.8 & $0-3.9$ & 93 & $0-549$ \\
\hline Podocarpus & 0.8 & $0.2-2.4$ & 102 & $22-333$ \\
\hline Piper & 0.8 & $0-2.3$ & 91 & $0-329$ \\
\hline Moraceae/Urticaceae (P3) & 0.7 & $0-2.0$ & 84 & $0-175$ \\
\hline Cyperaceae & 0.6 & $0.2-1.4$ & 72 & $22-175$ \\
\hline Menispermaceae & 0.5 & $0-4.3$ & 58 & $0-431$ \\
\hline Hedyosmum brasiliense & 0.4 & $0-1.6$ & 52 & $0-296$ \\
\hline Peperomia & 0.4 & $0-1.4$ & 43 & $0-122$ \\
\hline
\end{tabular}


Table 1 - Cont. ...

\begin{tabular}{|c|c|c|c|c|}
\hline Taxa & $\%$ & Min-Max & Influx & Min-Max \\
\hline Matayba & 0.3 & $0-1.4$ & 43 & $0-185$ \\
\hline Paullinia & 0.3 & $0-1.8$ & 23 & $0-108$ \\
\hline Cecropia & 0.2 & $0-0.8$ & 27 & $0-111$ \\
\hline Byrsonima & 0.2 & $0-1.2$ & 29 & $0-125$ \\
\hline Ficus & 0.2 & $0-2.0$ & 32 & $0-320$ \\
\hline Trema-type & 0.2 & $0-0.6$ & 29 & $0-87$ \\
\hline Amaryllis & 0.2 & $0-1.2$ & 20 & $0-93$ \\
\hline Clusia criuva & 0.2 & $0-0.6$ & 24 & $0-111$ \\
\hline Alnus & 0.1 & $0-0.4$ & 5 & $0-31$ \\
\hline Sum trees and shrubs & 88 & 77.9-96.7 & & \\
\hline Sum Asteraceae & 3.0 & $0.6-15.2$ & & \\
\hline Sum other herbs & 2.5 & $1-4.5$ & & \\
\hline Sum epiphytes & 1.0 & $0-4.4$ & & \\
\hline Sum ferns & 7.2 & $2.2-14.6$ & & \\
\hline Average influx & & & 12465 & $6172-22531$ \\
\hline
\end{tabular}

Table 2 - Average pollen rain data in percent (based on total pollen sum) and in influx (pollen grains $\mathrm{cm}^{-2} \mathrm{yr}^{-1}$ ) of the \pm 50 years old secondary forest (based on 4 pollen traps).

\begin{tabular}{l|r|r|r|r}
\hline \multicolumn{1}{c}{ Taxa } & \multicolumn{1}{c|}{$\%$} & \multicolumn{1}{c|}{ Min-Max } & Influx & \multicolumn{1}{c}{ Min-Max } \\
\hline Tapirira guianensis & 14.7 & $5.3-22.6$ & 592 & $163-987$ \\
Myrsine & 13.3 & $10.8-15.0$ & 570 & $248-1014$ \\
Melastomataceae & 9.5 & $2.2-29.0$ & 326 & $77-896$ \\
Arecaceae (Other) & 8.7 & $7.1-10.5$ & 358 & $162-574$ \\
Myrtaceae & 7.6 & $4.7-11.5$ & 335 & $168-774$ \\
Alchornea/Aparisthmium & 6.5 & $4.7-8.8$ & 248 & $174-320$ \\
Pinus & 5.1 & $4.3-6.3$ & 210 & $99-360$ \\
Tubuliflorae (Asteraceae) & 4.1 & $2.6-5.1$ & 182 & $59-347$ \\
Poaceae & 3.3 & $2.0-5.1$ & 149 & $45-267$ \\
Moraceae/Urticaceae P2 & 2.3 & $2.0-2.8$ & 93 & $63-147$ \\
Syagrus romanzoffiana & 1.7 & $0.2-3.0$ & 85 & $5-200$ \\
Vernonia & 1.4 & $0.4-1.8$ & 47 & $27-67$ \\
Cecropia & 0.7 & $0.2-1.4$ & 26 & $5-59$ \\
Podocarpus & 0.2 & $0.2-1.6$ & 47 & $7-93$ \\
Araucaria angustifolia & 0.3 & $0.2-0.6$ & 12 & $43-17$ \\
Cyathea & 25.0 & $8.5-74.7$ & 142 & \\
& & & & \\
Sum trees and shrubs & 82.7 & $79.6-88.6$ & & \\
Sum Asteraceae & 6.1 & $4.5-7.4$ & & \\
Sum other herbs & 4.2 & $2.2-7.1$ & & \\
Sum epiphytes & 0.2 & $0.0-0.4$ & & \\
Sum ferns & 38.2 & $18.3-91.4$ & & \\
& & & 4112 & $2296-6764$ \\
\hline
\end{tabular}




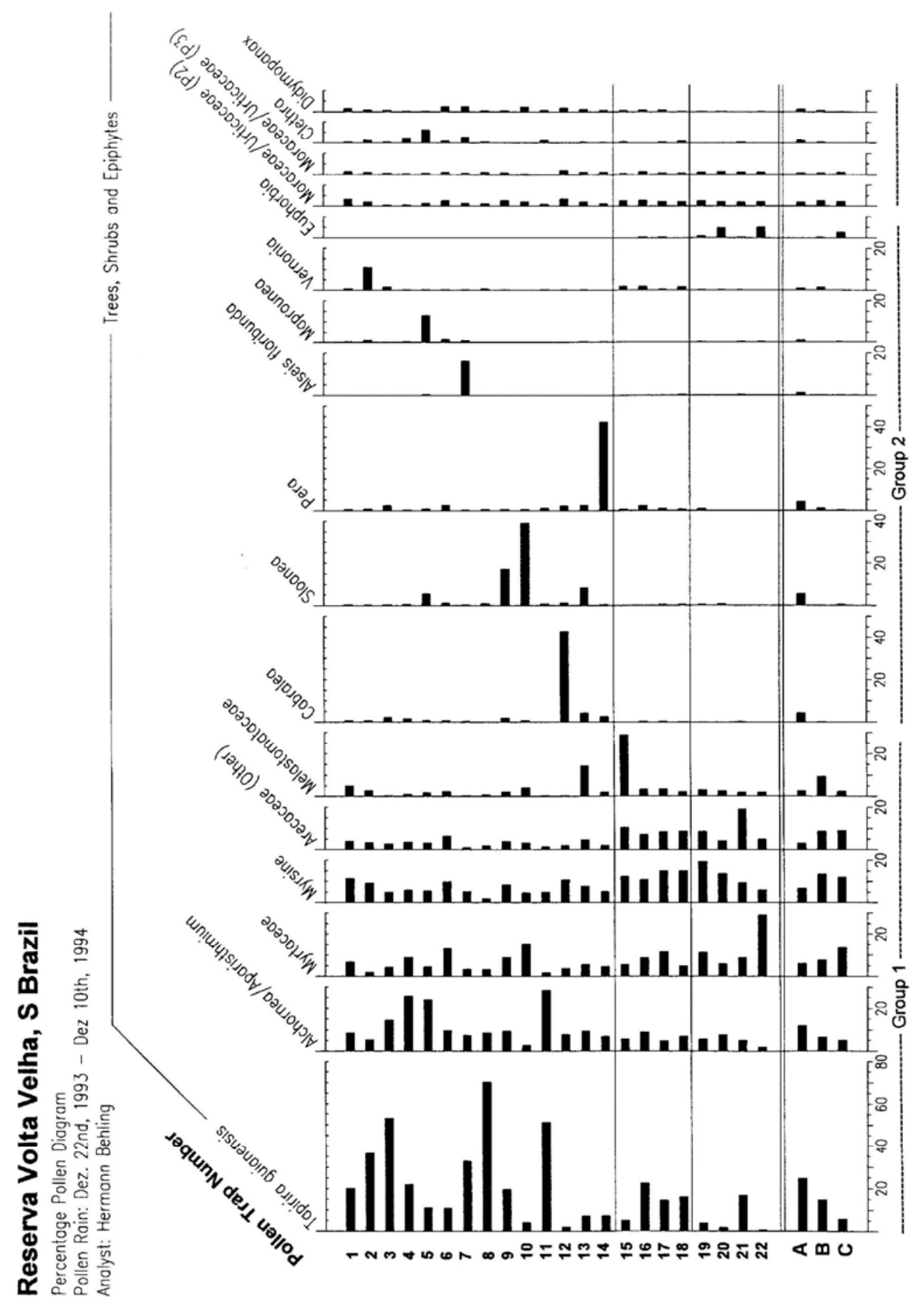

Figure 2 (Part a) - Percentage pollen diagram of the pollen trap samples from the native Atlantic rain forest (No.1 -14 , average is shown by A), the \pm 50 years old secondary forest (No. 15 - 18, average by B) and the 7 years old secondary forest (No. 19 - 22, average by C) (Adapted from Behling et al., 1997). 


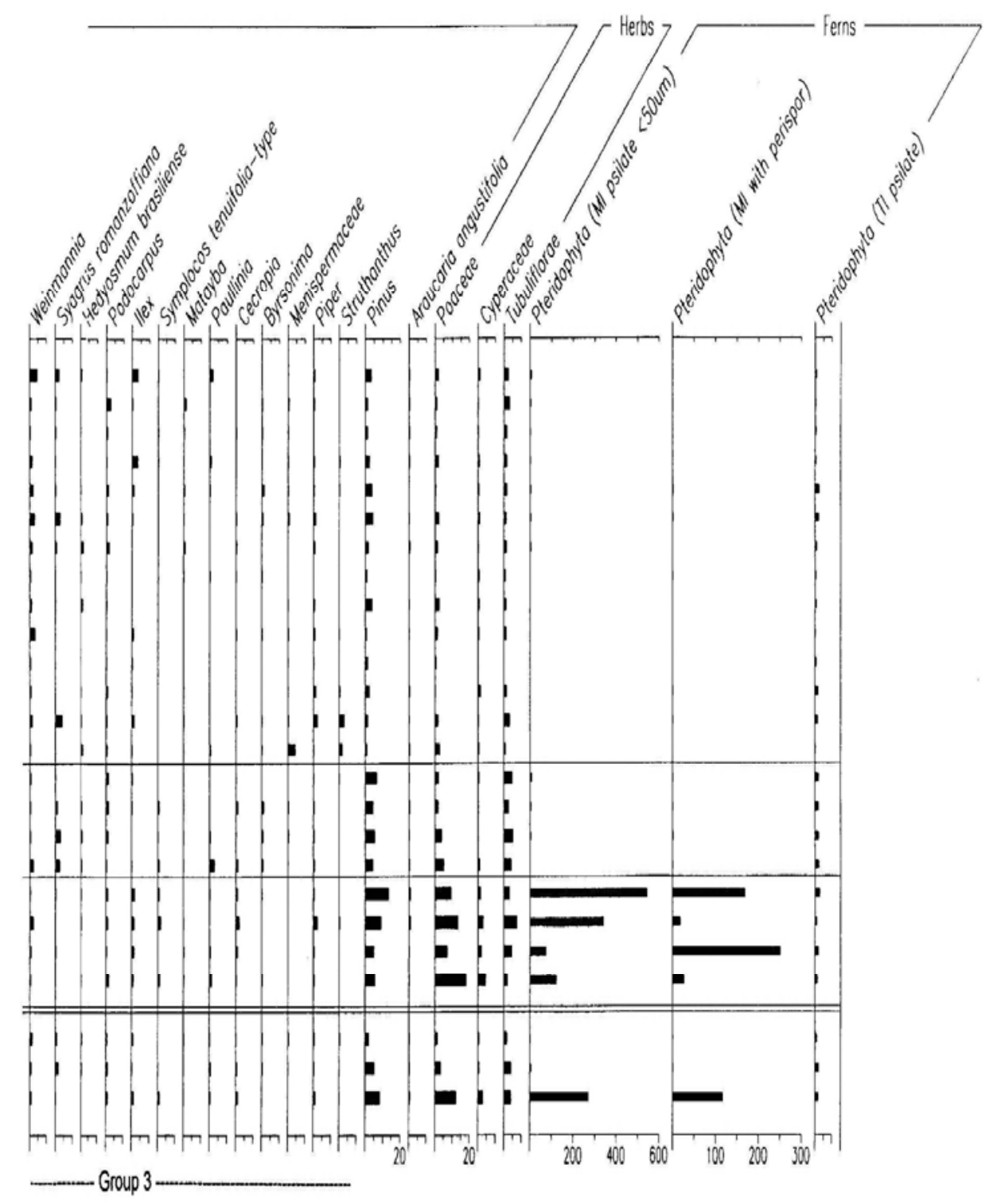

Figure 2 (Part b)- Percentage pollen diagram of the pollen trap samples from the native Atlantic rain forest (No.1 - 14, average is shown by A), the \pm 50 years old secondary forest (No. 15 - 18, average by B) and the 7 years old secondary forest (No. 19 - 22, average by C) (Adapted from in Behling et al., 1997). 
Tapirira guianensis

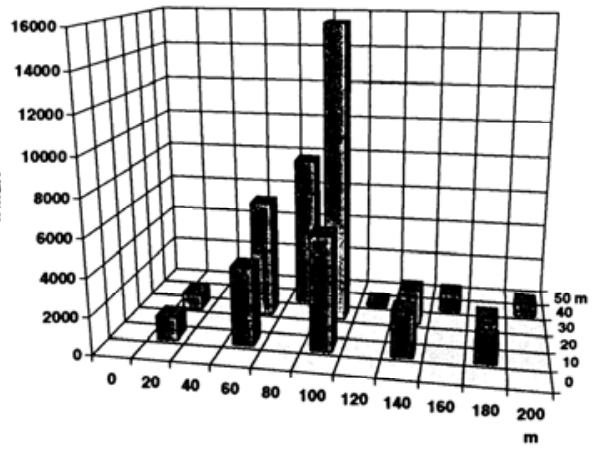

Myrtaceae

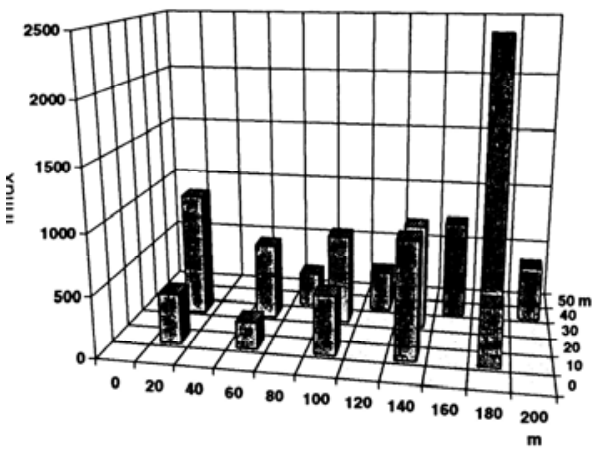

Arecaceae (Other)

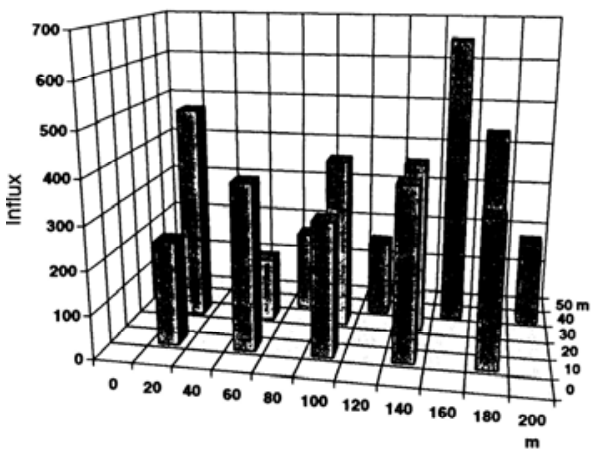

Podocarpus

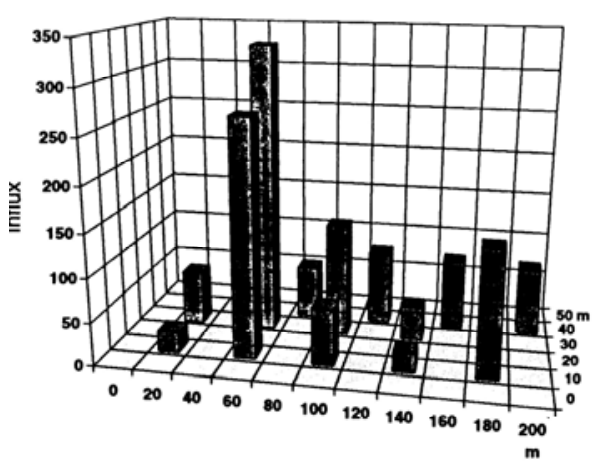

Alchornea/Aparısthmium

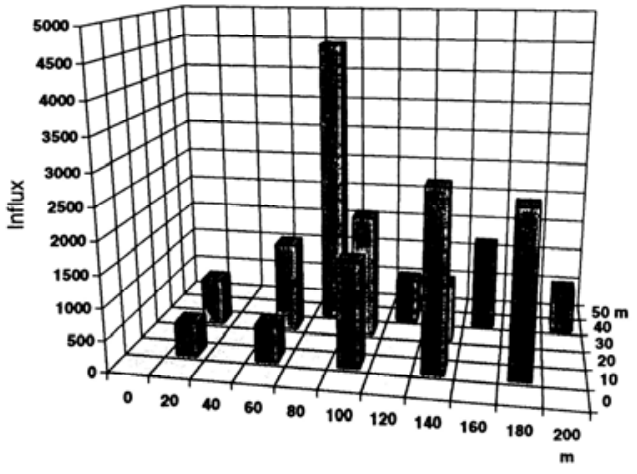

Myrsine

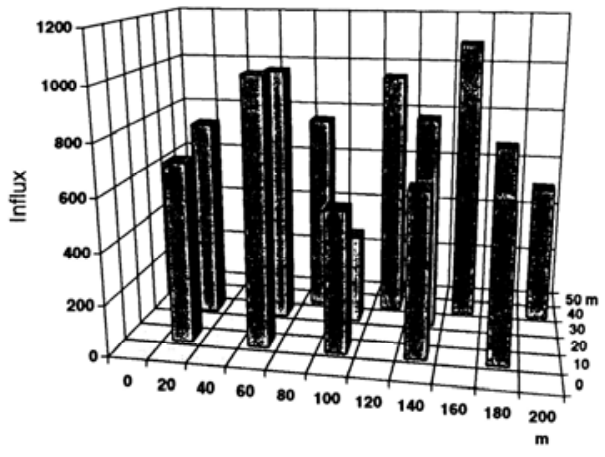

Cabralea

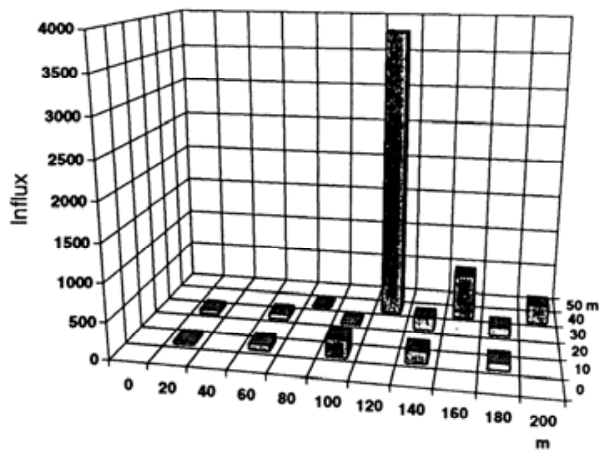

Pinus

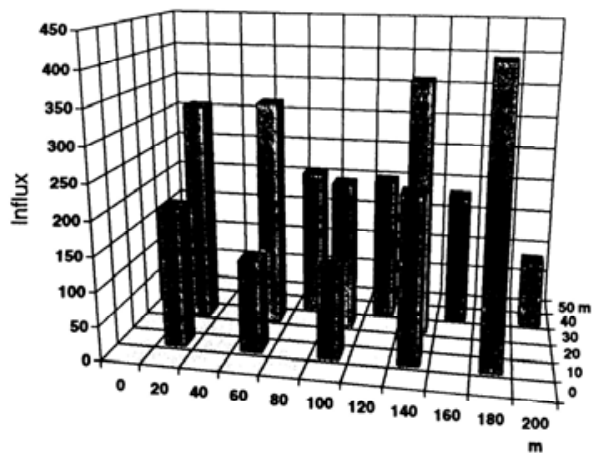

Figure 3 - 3-D representation of the influx of 8 pollen taxa in the one hectare plot area (Behling et al., 1997). 
Table 3 - Average pollen rain data in percent (based on total pollen sum) and in influx (pollen grains $\mathrm{cm}^{-2} \mathrm{yr}^{-1}$ ) of the 7 years old secondary forest (based on 4 pollen traps).

\begin{tabular}{|c|c|c|c|c|}
\hline Taxa & $\%$ & Min-Max & Influx & Min-Max \\
\hline Myrtaceae & 13.6 & $5.6-29$ & 564 & $153-1476$ \\
\hline Poaceae & 12.0 & $7.2-18.1$ & 454 & $154-921$ \\
\hline Myrsine & 12 & $6.0-19.4$ & 368 & $307-485$ \\
\hline Arecaceae (Other) & 9.1 & 4.1-19 & 372 & $111-990$ \\
\hline Pinus & 8.2 & $4.9-13.3$ & 249 & $218-277$ \\
\hline Tapirira guianensis & 5.8 & $0.0-17.1$ & 257 & $30-891$ \\
\hline AlchornealAparisthmium & 5.0 & $1.9-7.6$ & 163 & $90-258$ \\
\hline Tubuliflorae (Asteraceae) & 4.2 & $1.9-7.4$ & 146 & $48-238$ \\
\hline Cyperaceae & 2.7 & $1.4-4.3$ & 107 & $22-218$ \\
\hline Euphorbia & 2.7 & $0.2-5.1$ & 102 & $10-258$ \\
\hline Melastomataceae & 2.3 & $1.9-3.1$ & 78 & $51-99$ \\
\hline Moraceae/Urticaceae (P2) & 2.0 & $1.9-2.3$ & 72 & $38-99$ \\
\hline Cecropia & 1.1 & $0.4-1.9$ & 35 & $16-53$ \\
\hline Podocarpus & 1.2 & $0.4-1.9$ & 42 & $19-99$ \\
\hline Araucaria angustifolia & 0.6 & $0.4-0.8$ & 18 & $13-21$ \\
\hline Fern (Ml psilate < 50 um) & 269.3 & $72.5-543.6$ & 1382 & $382-2778$ \\
\hline Fern (Ml with perispor) & 115.6 & $18.5-249.7$ & 601 & $95-1316$ \\
\hline Sum trees and shrubs & 73.9 & $67.1-80.0$ & & \\
\hline Sum Asteraceae & 4.7 & 2.1-8.0 & & \\
\hline Sum other herbs & 15.3 & $9.9-23.0$ & & \\
\hline Sum epiphytes & 0.05 & $0.0-0.2$ & & \\
\hline Sum ferns & 389.8 & $151.4-717.6$ & & \\
\hline Average influx & & & 3667 & $1636-5211$ \\
\hline
\end{tabular}

Table 4 - Average pollen rain data in percent (based on total pollen sum) and in influx (pollen grains cm- $\mathrm{yr}^{-1}$ ) of the native Atlantic rain forest (based on 14 pollen traps) and the number of individuals on the one hectare plot.

\begin{tabular}{|c|c|c|c|c|}
\hline Taxa & $\%$ & Influx & Indiv.* & Influx/Indiv. \\
\hline Tapirira guianensis & 24.9 & 3610 & 121 & 30 \\
\hline AlchornealAparisthmium & 12.0 & 1485 & $77 / 233$ & 5 \\
\hline Myrsine & 6.8 & 752 & 25 & 30 \\
\hline Myrtaceae & 6.1 & 720 & 274 & 3 \\
\hline Sloanea & 5.4 & 736 & 37 & 20 \\
\hline Cabralea & 4.3 & 412 & 1 & $412 * * *$ \\
\hline Pera & 4.1 & 426 & 79 & 5 \\
\hline Arecaceae (Other) & 3.0 & 340 & 94 & 4 \\
\hline Melastomataceae & 2.7 & 322 & $28\left(65^{* *}\right)$ & 12 \\
\hline Pinus & 2.1 & 229 & - & \\
\hline Moraceae/Urticaceae (P2) & 1.8 & 205 & ---/--- & \\
\hline Weinmannia & 1.6 & 183 & 4 & 46 \\
\hline Poaceae & 1.5 & 173 & $\left(115^{* *}\right)$ & 2 \\
\hline Tubuliflorae (Asteraceae) & 1.5 & 179 & -- & \\
\hline Maprounea & 1.3 & 143 & 4 & 36 \\
\hline Alseis floribunda & 1.2 & 223 & --- & \\
\hline Vernonia & 1.2 & 134 & --- & \\
\hline Clethra & 1.2 & 153 & 20 & 8 \\
\hline Didymopanax & 1.2 & 155 & 2 & 78 \\
\hline Ilex & 0.9 & 93 & 38 & 3 \\
\hline Syagrus romanzoffiana & 0.8 & 93 & --- & \\
\hline Podocarpus & 0.8 & 102 & 4 & 26 \\
\hline
\end{tabular}


Table 4 - Cont. ...

\begin{tabular}{|c|c|c|c|c|}
\hline Taxa & $\%$ & Influx & Indiv.* & Influx/Indiv. \\
\hline Piper & 0.8 & 91 & $(5 * *)$ & 18 \\
\hline Moraceae/Urticaceae (P3) & 0.7 & 84 & ---/--- & \\
\hline Cyperaceae & 0.6 & 72 & --- & \\
\hline Menispermaceae & 0.5 & 58 & 4 & 15 \\
\hline Hedyosmum brasiliense & 0.4 & 52 & --- & \\
\hline Peperomia & 0.4 & 43 & $(7 * *)$ & 6 \\
\hline Struthanthus & 0.4 & 53 & unknown & \\
\hline Bromeliaceae & 0.3 & 28 & $($ very high**) & \\
\hline Araucaria angustifolia & 0.3 & 32 & - & \\
\hline Matayba & 0.3 & 43 & 15 & 3 \\
\hline Paullinia & 0.3 & 23 & 2 & 12 \\
\hline Cecropia & 0.2 & 27 & --- & \\
\hline Byrsonima & 0.2 & 29 & 8 & 4 \\
\hline Ficus & 0.2 & 32 & 3 & 11 \\
\hline Trema-type & 0.2 & 29 & --- & \\
\hline Amaryllis & 0.2 & 20 & --- & \\
\hline Clusia criuva & 0.2 & 24 & 3 & 8 \\
\hline Alnus & 0.1 & 5 & --- & \\
\hline
\end{tabular}

* Number of individuals on the hectare plot with a $\mathrm{DBH}>5 \mathrm{~cm}$, based on species, genera or family level respectively.

$* *$ Number of individuals with a DBH $<5 \mathrm{~cm}$

$* * *$ Strong local effect

\section{CONCLUSION}

The one year pollen trapping record from an Atlantic rain forest in South Brazil indicated that modern pollen rain was high, despite the very high rate of entomophilous pollination. Tropical taxa with abundant pollen in the assemblages were in general as frequent as the individuals in the forest and rare pollen taxa were rare as individuals. Several abundant tropical rain forest species were very rare or not represented in the pollen spectra, probably because of the very low pollen production or the poor preservation, as in the case of Ocotea (Lauraceae). Several rare species were not found in the pollen spectra, which, therefore, represented only a part of the vegetation. Secondary forests had a pollen rain assemblage clearly different from the undisturbed Atlantic rain forest and could be distinguished by pollen analysis. Pollen grains of herbs and fern spores were significantly higher in secondary forests than in the undisturbed rain forest and the order of abundance of pollen grains of secondary forests was also different.

These results have to be considered when interpreting fossil pollen data and modern pollen rain data from disturbed forests. Furthermore, for the interpretation of pollen records from modern pollen rain data one must consider the different environments (e.g. forest, non-forest vegetation types) from which pollen rain data were obtained and from where palaeo-pollen records were taken (e.g. lake, swamp, bog). The pollen rain data in this study were obtained from one year, whereas analyzed sediment deposits often represent many years. Data from single pollen traps under tropical forests are very variable and often show a very local assemblage (Behling, 1993). Several pollen traps or surface samples for one vegetation type are necessary to exclude local effects.

\section{ACKNOWLEDGMENTS}

We express our thanks to Machado family for the permission to research in their reserve and the two anonymous reviewers for their helpful comments and suggestions.

\section{RESUMO}

Estudou-se a relação entre a Floresta Tropical Atlântica sul brasileira e a chuva polínica atual através de coletores de pólen. $O$ estudo foi realizado em uma parcela de um hectare de floresta não perturbada localizada na Reserva Volta Velha $\left(26^{\circ} 04^{\prime} \mathrm{S}, 48^{\circ} 38^{\prime} \mathrm{W}, 9 \mathrm{~m}\right.$ s.n.m. $)$ e duas outras 
parcelas de floresta secundária $( \pm 50$ e 7 anos de idade). Cerca de 248 espécies arbóreas, arbustivas e herbáceas (excluindo epifitas), englobadas em 50 familias estavam representadas por 126 diferentes tipos de pólen e esporos (incluindo taxa não locais). $\mathrm{Na}$ área não perturbada, a média do fluxo de entrada da chuva polínica foi de 12465 grãos de pólen por $\mathrm{cm}^{2} /$ ano. Nas áreas de \pm 50 anos e 7 anos correspondentes a estádios florestais secundários o fluxo de entrada foi relativamente baixo (4112 e 3667 grãos por $\mathrm{cm}^{2} / \mathrm{ano}$, respectivamente) comparativamente à área não perturbada. A ocorrência de grãos de pólen de herbáceas e esporos de pteridófitas foi significativamente maior nas áreas secundárias do que na área não perturbada.

\section{REFERENCES}

Atlas de Santa Catarina. (1986), Gabinete de Planejamento e Coordenação Geral, Rio de Janeiro, Brasil. 173 pp.

Behling, H. (1993), Untersuchungen zur spätpleistozänen und holozänen Vegetations- und Klimageschichte der tropischen Küstenwälder und der Araukarienwälder in Santa Catarina (Südbrasilien). Dissertationes Botanicae 206, J. Cramer, Berlin Stuttgart. 149 pp.

Behling, H. (1995), Investigations into the Late Pleistocene and Holocene history of vegetation and climate in Santa Catarina (S Brazil). Vegetation History and Archaeobotany, 4, 127-152.

Behling, H.; Negrelle, R. R. B. and Colinvaux, P. A. (1997), Modern pollen rain data from the tropical Atlantic rain forest, Reserva Volta Velha, South Brazil. Review of Palaeobotany and Palynology, 97, 287-299.

Bush, M. B. (1992), A simple yet efficient pollen trap for use in vegetation studies. Journal of Vegetation Science, 3, 275-276.

Klein, R. M. (1978), Mapa fitogeográfico do Estado de Santa Catarina.

Flora Ilustrada Catarinense. Herbário "Barbosa Rodriges", Itajaí.
Martin, L.; Suguio, K.; Flexor, J. M. and Azevedo, A. E. G. (1988), Mapa geológico do Quaternário costeiro dos Estados do Paraná e Santa Catarina. Série Geologia 28. Seção Geologia Básica, 18, 1-40.

Negrelle, R. R. B. (1995), Composição florística, estrutura fitossociológica e dinâmica de regeneração da floresta Atlântica na reserva Volta Velha, Mun. Itapoá, SC. Ph.D. thesis, Curitiba.

Negrelle, R. R. B. (2002), The Atlantic forest in the Volta Velha Reserve: a tropical rain forest site outside the tropics. Biodiversity and Conservation, 11 : (5), 887-919.

Nimer, E. (1986), Climatologia do Brasil. 2. ed. Rio de Janeiro: IBGE.

\section{Rodriges", Itajaí.}

